\title{
Corpus
}

Archivos virtuales de la alteridad americana

Vol 6, No 2 2016

Julio / Diciembre 2016

\section{Slavery and captivity in Álvar Núñez Cabeza de Vaca's 1542 La Relación}

Esclavitud y Cautividad en La Relación (1542)de Álvar Núñez Cabeza de Vaca

\section{Ramón Sánchez}

\section{(2) OpenEdition}

\section{Journals}

\section{Electronic version}

URL: http://journals.openedition.org/corpusarchivos/1682

DOI: 10.4000/corpusarchivos. 1682

ISSN: $1853-8037$

\section{Publisher}

Diego Escolar

\section{Electronic reference}

Ramón Sánchez, «Slavery and captivity in Álvar Núñez Cabeza de Vaca's 1542 La Relación », Corpus [En línea], Vol 6, No 2 | 2016, Publicado el 22 diciembre 2016, consultado el 30 abril 2019. URL : http:// journals.openedition.org/corpusarchivos/1682 ; DOI : 10.4000/corpusarchivos.1682

This text was automatically generated on 30 April 2019. 


\title{
Slavery and captivity in Álvar Núñez Cabeza de Vaca's 1542 La Relación
}

\author{
Esclavitud y Cautividad en La Relación (1542)de Álvar Núñez Cabeza de Vaca
}

\author{
Ramón Sánchez
}

1 Álvar Núñez Cabeza de Vaca's 1542 La Relación que dio Álvar Núñez Cabeça de Vaca de lo acaescido en las Indias... continues to be mined for information about the early conquest period of the Americas. Scholarly explorations of different Spanish conquerors' accounts offer opportunities to discern social/cultural layers of the Spanish conquering enterprise. The examination by diverse scholars of Cabeza de Vaca's discursive representation of America in La Relación has resulted in varied insights and/or interpretations of the work. Approaches that deal, for example, with an evolving eyewitness experience, a captivity account, and Cabeza de Vaca's attempt to validate his royal service allow one to perceive and recognize the emergence of discursive relationships of knowledge in La Relación's intersecting historical, cultural, and social factors. Yet challenges remain in studies of Cabeza de Vaca's account, in part, because of the persistent need to better understand how meaning is constructed in the narrative.

2 First, one must note several significant versions of Cabeza de Vaca's narrative, which include the "Joint Report" as contributor, Oviedo's use of the "Joint Report" for an account in his Historia general y natural, the 1542 La Relación, Oviedo's makes an addition to his earlier account of the Pánfilo de Narváez Expedition after reading the 1542 narrative, the 1555 edition of La Relación which re-conceptualizes the original narrative, and Las Casas's utilization of Cabeza de Vaca's work to support his discourse of pacification.

In the 1700s, Cabeza de Vaca's account became tied to regional histories in which the evangelizing role of the castaways became fundamental. Antonio Ardoino's Examen apologético de la histórica narración de los naufragios, peregrinaciones i milagros de Álavr Núñez Cabeza de Baca en las tierras de la Florida, i del Nuevo México... (1736) is a refutation of Honorio Philopone's denial of Cabeza de Vaca's miracles in his narrative. Drawing from Fray Antonio Tello's Crónica miscelánea de la sancta provincia de Xalisco (1650-1653), Matías 
de la Mota Padilla in Historia del reino de Nueva Galicia en la América septentrional (1742) maintains the veracity of the pilgrims' miracles and the fact of their exemplary lives.

Analyses of Cabeza de Vaca's La Relación offer to reveal articulations of the modes of conceptualization that address diverse discursive elements of the Conquest. For instance, some critical approaches to La Relación seek to establish the route of his journey, probe the meaning of a narrative of failure, delve into it as a demystified narrative, examine it as a literary construct, explore how his shaman role shifts his imperial perspective, inquire how "fear" is an important aspect in understanding the account, and explore the narrative as a discourse of royal solicitation.

5 The historiography of Cabeza de Vaca's La Relación in the United States initially was dominated by a historical perspective on interpretations of Cabeza de Vaca's route, especially in connection to Texas. An argument for this approach is that a more precise route interpretation contributes to a better understanding of early Texas ethnography, geography, and biology. In such a perspective, Cabeza de Vaca and his companions are seen as important for being the first non-Indian "pioneers" of Texas, who lived continuously for many years in the area that would become the "Lone Star" State. Some of the scholars involved in this type of study are: Brownie Ponton and Bates $\mathrm{H}$. McFarland, "Alvar Núñez Cabeza de Vaca: A Preliminary Report on His Wanderings in Texas," (1898); O. W. Williams, "Route of Cabeza de Vaca in Texas," (1899); Bethel Coopwood, "The Route of Cabeza de Vaca," $(1899,1900)$; James Newton Baskett, "A Study of the Route of Cabeza de Vaca," (1907); Harbert Davenport and Joseph K. Wells, "The First Europeans in Texas, 1528-1536," (1918, 1919); Alex D. Krieger, "Un nuevo estudio de la ruta seguida por Cabeza de Vaca a través de Norte América” 1955; T.N. Campbell and T.J. Campbell, "Historic Indian Groups of the Choke Canyon Reservoir and Surrounding Area, Southern Texas" (1981). This scholarship attempts to determine what precise route Cabeza de Vaca and his companions traveled.

6 However, other historical explorations and interpretations of the La Relación emerge, raising questions about literary and historical distinctions. David Lagmanovich's "Los Naufragios de Álvar Núnez como construcción narrativa" (1978) gives an analysis of the fictional aspect of the account. Robert Lewis, in “'Los naufragios' de Alvar Núñez: historia $y$ ficción" (1982), delves into the tension between the historical and literary in Cabeza de Vaca's account. Lewis analyzes the "prohemio" as metatext in Cabeza de Vaca's work, revealing the tensions between the autobiographical, relación de servicios, and the preface's claim of truthfulness of the report. He points out that Cabeza de Vaca resorts to literary discursive elements to relieve tension and to persuade. Antonio Carreño in “ Naufragios' de Alvar Núñez Cabeza de Vaca: Una retórica de la crónica colonial" looks at the literary aspect of colonial narratives that use the known to describe the unknown (Carreño 1987 pp.509, 510). Carreño contributes to the study of the dichotomy of history and fiction by noting the strain in the suspension of disbelief between experience of reality as history and the imagined reality of literature. He connects Cabeza de Vaca's account of a journey with the picaresque novel, viewing Cabeza de Vaca's hardship as the process that turns him into an antihero.

7 In Cabeza de Vaca's La Relación, narrative, Sylvia Molloy looks into the construction of identity through dialogue, especially once Cabeza de Vaca and his companions became dispossessed castaways and had to deal with indigenous people. As a consequence, Molloy addresses Cabeza de Vaca's difficult process of learning and communicating about a very different world as well as the tension between the "I" as participant in the text and the 
one who supposedly stands as witness. In "Naufragios e Infortunios" (1987), Lucía Invernizzi Santa Cruz examines the discourse of the failure that turns into success and refers to the textual Cabeza de Vaca as the new man, which comes into being through coping with his adversity and his interaction with indigenous peoples. Silvia Spitta sees La Relación as one of the earliest examples of Spanish transculturation. In her "Chamanismo y cristianidad" (1993), she explores in La Relación the intercultural aspect derived from the subjugation of Cabeza de Vaca by the natives and points out his becoming a shaman-in order to survive -is the means for substituting information for heroic action (Spitta 1993, pp. 317, 318).

In the 1990s, Beatriz Pastor Bodmer's The Armature of Conquest contributes to the intellectual history of the discovery and conquest of the Americas, focusing on five texts, including Cabeza de Vaca's Naufragios. She states that the "initial discourse on the conquest of America" is structured by "success," which for Columbus turns out to be "problematic". However, she argues, Cabeza de Vaca's Naufragios, which concerns a failed expedition, is a "perfect example of the discourse of demythification," one that undermines the established Spanish imperial order. She also points to the parallels between Cabeza de Vaca's "demythifying of the natives" and "the critical thinking of Las Casas" (Pastor 1992, pp. 116, 130, 144, 145).

Rolena Adorno in "The Negotiation of Fear in Cabeza de Vaca's Naufragios" avers there is a gap between what La Relación contains and what others say it contains. She notes, for instance, the noticeable gap in Cabeza de Vaca's account between the "impoverishment of the land about which he wrote and the visions of wealth that he conjured up for the emperor" (Adorno 1991, pp. 163). She considers "that interpretive gap" in La Relación by focusing on the aspect of "fear" in Cabeza de Vaca's narrative and Oviedo's use of his account (Adorno 1991, pp. 164, 167). Adorno explores the subject of fear as a "weapon employed by both" the indigenous people and the Spaniards, examining the Spaniards' fear of the natives; the natives' fear of the Spaniards; and Cabeza de Vaca's acquisition of control of fear (Adorno 1991, p. 167). The 1999 three-volume study of Álvar Núñez Cabeza de Vaca by Rolena Adorno and Patrick Charles Pautz raises the standards of scholarship applied to the account. They not only supply a translation of the account, but address historical aspects and provide critical analysis, as well as critically utilizing ignored sources, e.g., some of Fernández de Oviedo y Valdés' work.

Studies have expanded the discussion about the Spanish conqueror as well as the indigenous people. There have also been contributions on African aspects of La Relación, e.g., Cassandra Smith in her "Esteban, Cabeza de Vaca's 'Relación', and a Narrative Negotiation" points to "a level of complexity, of inconsistency, in Esteban's representation" (Smith 2012, p. 268). Africans are a ubiquitous part of Spanish conquest campaigns in the Americas and play a prominent role in the long-term development of the Spanish imperial enterprise.

11 In my discursive study of Cabeza de Vaca's 1542 La Relación, I examine how Cabeza de Vaca communicates the nature of his captivity in contrast to that of the African slave. In this case, I scrutinize the cristiano imperial superaddressee in Cabeza de Vaca's narrative as a means through which one can decipher his articulation of the African slave role in opposition to his, which furthers the exploration of the construction of knowledge and relationships in La Relación.

In Álvar Núñez Cabeza de Vaca's (1542) La Relación que dio Álvar Núñez Cabeça de Vaca de lo acaescido en las Indias..., his imperial discourse distinguishes his ordeal as a true cristiano, who as slave/captive becomes a redeemer (Cabeza de Vaca 1542, sigs. A2 $\left.{ }^{\mathrm{r}}, \mathrm{A} 2^{\mathrm{v}}\right) .{ }^{1}$ However, 
no special designation is acknowledged for the castaway Estevanico el negro, who also experiences enslavement/captivity. Cabeza de Vaca models his discourse on a presupposed authoritative, higher imperial audience, who stands above all who participate in a dialogue (a superaddressee). Rising from his status as slave to redeemer in the indigenous world, Cabeza de Vaca presents himself as the true cristiano, who participates in the expanding imperial project by bringing to the natives the true faith and lord. In his account, African slaves do not fit into Cabeza de Vaca's category: instead, their marginalization is taken for granted. In this article, I first address Cabeza de Vaca's slave/captive status in parallel to African bondage (mainly represented by Estevanico). This involves commenting on other roles Cabeza de Vaca and his castaway companions perform in the process of cultural adaption and physical survival, e.g, slave, trader, and físico (healer). Second, I examine the discursive aspect of Cabeza de Vaca's superaddressee's qualitative cristiano differences concerning his "esclavitud"/"catividad" [ cautividad] (enslavement/ captivity) and an African's bondage, which reveals how categories of servitude remained the same in La Relación.

For the analysis, I use Mikhail Bakhtin's concept of the superaddressee, who in a dialogue is taken to be the participant holding the authentic and unifying view of things, subordinating all to its contextual definition (Bakhtin 1986, pp. 126, 137). Though not physically present in a dialogue, each party involved in an exchange appeals to an ultimate listener as standing above and delimiting responses and understandings. However, speakers can point to different superaddressees, who can be dissimilar to each other by degree or at times entirely. The superaddressee is very much a part of a dialogue and is in flux itself, for it is in the process of development as it contributes to the exchange.

In La Relación, the dominant orientation of utterances does not question the existing cristiano imperial enterprise or wave between two mutually exclusive social positions, e.g., slavery or no-slavery. Instead, Cabeza de Vaca's superaddresssee approves of qualitative cristiano differences between Cabeza de Vaca's and an African's bondage. In such a context, through God's grace, Cabeza de Vaca's status changes from slave/captive to redeemer, a narrative process that confirms he remains a true cristiano. Scrutinizing a cristiano imperial superaddressee's manner of distinguishing Cabeza de Vaca's slavery from that of African people in La Relación will involve examining (1) the cristiano imperial superaddressee's definition and subordination of the African other, (2) Cabeza de Vaca's superaddressee's reinforcement of African bondage while reacting to the neo-feudal conqueror, and (3) the presuppositions in the cristiano imperial superaddressee's silence concerning Africans, specifically Estevanico.

\section{Succinct Backround}

15 In 1542, Cabeza de Vaca publishes La Relación in Zamora, Spain: an account about the failed conquering Pámfilo de Narváez Expedition (1527-1536) in the Americas. Cabeza de Vaca, as treasurer of the Expedition, represents the Spanish Crown's economic/political interests, which conflict with those of the head of the expedition Governor Narváez, who seeks his own financial profit (Goodman 2005, pp. 235, 236). Cabeza de Vaca, along with the African slave Estevanico, is among the 300 men who enter inland into Florida in 1528 but end up unable to reconnect with the ships (Adorno and Pautz 1999a, p. 374). Consequently, the stranded men construct barges and launch themselves into the sea, 
ending up shipwrecked somewhere on the coast of the Gulf of Mexico in present day northern Mexico or Texas, U.S.A.

From there, Cabeza de Vaca, along with three companions (Estevanico the slave, Dorantes [Estevanico's master], and Castillo), journeys inland westward, trying to reconnect with cristianos (Oviedo 1992, p. 155). ${ }^{2}$ During this time, Cabeza de Vaca acknowledges the African slave Estevanico, whose status does not change. The castaways finally encounter a Spanish slave raiding party in 1536 near the Sinaloa River close to the Pacific Ocean. Cabeza de Vaca then meets Melchior Díaz, Chief Justice of Culiacán, and joins him in subduing the natives of this region. In 1537, he leaves for Spain and reaches the port of Lisbon on 9 August 1537. Dorantes, who owns Estevanico, sells him to Viceroy Antonio de Mendoza, and the African slave dies as a guide for Fray Niza's Reconnaissance Expedition (1539).

\section{The Cristiano Imperial Superaddressee: Definition and Subordination of the African Other}

17 Cabeza de Vaca's narrative utterances related to African slavery are given substance by an imperial context that contains some extra-textual reality and/or inter-textual and inter-utterances (Bakhtin 1986, pp. 83, 114). The Crusades allowed Jewish massacres and fueled intolerance by establishing a process of conquest, colonization, and conversion of "uncivilized" people, such as the Slavs. ${ }^{3}$ In the cristiano struggle with Muslims in the Iberian Peninsula, the Spanish Crown's power and jurisdiction entailed the missionary charge to convert the subjugated, assimilating the non-Christian enemy as well as enslaving the Moro (Moor) (Fletcher 1992, pp. 135, 136, 137, 138, 147). In addition, by the fourteenth and early fifteenth centuries, in the Iberian Peninsula, dark skin color became associated with being a slave (Fredrickson 2002, pp. 28, 29; Novikoff 2005, p. 30). As the Reconquista proceeds, the Spanish imperial domain evolved and intolerance grew toward non-cristianos of any sort or those suspected as not being truly Christian. ${ }^{4}$ As part of the Reconquista, between 1391 and 1492, large numbers of non-Christians were converted under duress (e.g., Muslims and Jews), leading those claiming to be true cristianos to question who is truly one, and the establishing of discerning categories of difference (Nirenberg 2007, p. 75; Voloshinov 1973, p. 10). Politically this resulted in attacks on Moriscos, discrimination against Jewish converts (conversos), and denial of rights to groups of people through the notion of purity of blood (limpieza de sangre) (Fredrickson 2002, pp. $34,35,23,32,33)$.

Utterances of entitlement-supposedly derived from an unerring cristiano imperial superaddressee-emerge, for instance, asserting a Castilian messianic nationalism, the providential mission of the establishment of the universal empire, and acknowledging Spanish monarchs as the "greatest defenders and propagators of the universal Catholic faith" (Elliott 1989, p. 8; Dandelet 2001, p. 32). Through this superaddressee-endorsed discourse, the Spanish Crown perceives the "existence of non-Christian nations" as "a religious, political, and military challenge to the orbis christianus" (Rivera 1992, p. 35). Consequently, the true cristiano must uphold subjugation, conversion to Catholicism, and privilege according to rank and cristiano category. An imperial superaddressee arises that recognizes the distinctive status of different types of cristianos, e.g., incomplete cristiano slaves. 

history, the novel, and the enigmatic and prophetic-all held together by the theme of a journey from a barbaric to a cristiano/Hispanic civilization (Carreño 1987, pp. 512, 509). Cabeza de Vaca shapes his redeemer pilgrimmage in La Relación by referencing his criteria to a cristiano imperial ultimate witness and judge. The "Prohemio" (foreward) to Charles V in La Relación comes across as a "metatexto historigráfico" (historiographical metatext) through which Cabeza de Vaca justifies his account of the failed expedition by supporting the imperial enterprise through his narrated memory, which chronicles his true cristiano ethos (Lewis 1982, pp. 682, 684). Cabeza de Vaca's appeal to a cristiano/Hispanic familiar ideological background makes his journey from his esclavitud to freedom intelligible to his cristiano/Hispanic reader, presenting him as progressing from loss to recovery and from perdition to salvation, emphasizing "his role as passive, self-effaced recorder of things 'experienced"' (Bauer 2003, pp. 69, 72).

Unable to show material gain (e.g., the conquest of land and acquisition of wealth), he needs the contents of $L a$ Relación to be recognized by the imperial authority of the emperor as having merit (Invernizzi 1986, pp. 8, 9). Cabeza de Vaca attempts to overcome the failure of the Narváez Expedition -specifically embodied in his esclavitud/cautividadby talking about his captivity through familiar cristiano/Hispanic cultural concepts, which assist him in redefining himself as a true cristiano. Cabeza de Vaca understands that the idea of him becoming a native will lead to rejection by his fellow Spaniards. He would no longer fit into the frame of reference derived from the cristiano imperial superaddressee, except in terms of disloyalty and betrayal, becoming another Guerrero, who collapses into the other (Greenblatt 1991, pp. 141). Consequently, in Cabeza de Vaca's narrative transformation of the Narváez Expedition from failure to success, his redeemer role is critical, for such discourse asserts hierarchical relationships within the imperial endeavor, which elevates Cabeza de Vaca but marginalizes African slaves.

As castaway, he takes on different roles (e.g., trader, físico) in order to survive in one after another non-cristiano/Hispanic context. In his account, he demonstrates he understands "the practices of various [indigenous] groups as pertaining to a related set of patterns or principles" (Adorno 1991, pp. 168). This does not mean he abandons his cristiano/Hispanic conceptions when taking up roles defined by an indigenous context. However, his discursive orientation is not smooth.

To be redeemed from his servitude, he interprets his roles as fitting the vision of a cristiano imperial superaddressee. Cabeza de Vaca describes himself as a self-employed trader for unspecified periods of times and says little about the role in La Relación. The first time Cabeza de Vaca takes up the occupation of trader he may have invested about two years in it (Cabeza de Vaca 1542, sig. D4r.). It appears he leaves that occupation only to then take it up again, maybe after five years, for a shorter period of time, and he is joined in the occupation by his companions: Castillo, Dorantes, and Estevanico (Cabeza de Vaca 1542, sig. E8 ${ }^{v}$ ). As físico (healer), Cabeza de Vaca emphasizes the Christian elements he utilizes in such a role through which he then achieves the greater good sanctioned by the imperial superaddressee: e.g., redemption of the natives (Spitta 1993, pp. 321; Adorno 1991, pp. 180).

23 Under difficult circumstances, Cabeza de Vaca presents his trader and físico roles as necessary for getting food and better treatment and learning about routes to be used for escaping the non-cristiano lands, but most importantly, his time in bondage leads to his liberation redeemer role (Cabeza de Vaca 1542, sigs. D3 ${ }^{\mathrm{r}}$, D3 ${ }^{\mathrm{v}}$ ). Estevanico also takes on all

Corpus, Vol 6, No 2 | 2016 
the roles Cabeza de Vaca does; however, in La Relación, though his existence as a person is not denied, he is not allowed an exceptional role. He is relegated to a "subordinate position... precisely because he is 'the black"' (Pastor 1992, pp. 143).

Cabeza de Vaca's cristiano imperial superaddresssee maintains the emperor's writ which cannot be diluted just because he is a slave/captive to non-Christian people, acknowledging his true cristiano entitlement, for he is committed to an emperor-centered endeavor of peaceful conquest. Still Cabeza de Vaca's castaway situation gives rise to a dialogic struggle-over the conquering enterprise, his slave/captive status, and who controls subjugated labor-with the neo-feudal (encomienda-oriented) conqueror, who appeals to la Reconquista (Reséndez 2007, pp. 49; Cabeza de Vaca 1542, sig. A2 ${ }^{\mathrm{r}}$ ).

In La Relación, interrelated and internalized Christian utterances spring from the imperial superaddressee, e.g., Augustine of Hippo's utterances about God judging sin as the "prime cause of slavery" and sanctioning just war led by a legitimate authority (a Christian emperor) to repress and correct, for "having a unified community of the faithful" vindicates the use of violence (Garnsey 1996, p. 217; Salisbury 2006, pp. 212, 211, 210; Rivera 1992, p. 185). However, whether the just or unjust wins, God's judgment is that he who is captured can be enslaved (Garnsey 1996, p. 217). In the Narváez Expedition, two friars are to determine whether a just war is appropriate to undertake the native's conversion. Cabeza de Vaca and neo-feudal conquerors take for granted cristiano good intentions and royal leadership in a just war and as self-evident that violence is necessary for advancing it, for unlike them, the "other" just fights to defend his/her sin (Cabeza de Vaca 1542, sigs. F3 ${ }^{\mathrm{v}}$, H6ri ; Salisbury 2006, pp. 210, 211, 203; Columbus 1994, p. 153). In the imperial scheme, the Africans are depicted as people who reject Christianity and, therefore, can be enslaved in a just war in order to Christianize them.

The cristiano imperial language incorporates and limits the African slaves' response and relationships by seeking to "destroy, not reproduce, African group identity" and not allowing the recovery of their former cultural/political patterns (Martínez 2000, p. 26; Restall 2000, pp. 172,173, 175; Hensel 2007, p. 18; Lampe 2008, pp. 16, 18). For instance, the religious language of papal decrees on slavery strengthens the Crown's hierarchical categories, reinforcing the African slave's ties to the empire (Rivera 1992, p. 194; Vinson 2000 , pp. 471, 472, 495, 496). Also, the Spanish conqueror's use of the term "negro" assumes such a person has sub-Saharan ancestry, evoking negative connotations and an inferior social position (Smith 2012, p. 277). Consequently, in the early 1500s Caribbean, Spanish conquerors utilize the word "negro" as the equivalent to slave (Forbes 1993, 79).

Cabeza de Vaca's superaddressee establishes identity, dominant and subordinate voices, degrees of acceptance, as well as defining experiences and acceptable means of engagement (Vinson; 2000, pp. 474, 475). In La Relación, Cabeza de Vaca's redeemer identity is constructed, in part, in oppositional terms to Africans bondage. He echoes elements of Augustine of Hippo's discourse, such as claiming grace as proof that he is a true cristiano, which sets him apart as redeemer and strengthens the simulacrum role of $e l$ negro (Garnsey 1996, pp. 215, 214). For instance, when the castaway Cabeza de Vaca falls ill while with the Capoque during the blackberry eating season on the mainland, many of the remaining cristianos come from the isla de malhado to visit him, and Estevanico is mentioned with the added phrase "el negro" implying his subservient status (Cabeza de Vaca 1542, sig. D3 ${ }^{\mathrm{r}}$ ). By identifying Estevanico as negro, Cabeza de Vaca contrasts a recent cristiano to him, an old one. His cristiano superaddressee sustains the interpretation of Estevanico as one who fails to be a complete, authentic cristiano in comparison to him. 


\section{Cabeza de Vaca's Superaddressee's Reinforcement of African Bondage}

Cabeza de Vaca's main discursive struggle is with the neo-feudal conqueror over whose superaddressee is the valid one (who gives or takes away legitimacy), for this is crucial concerning his slave/captive status. The neo-feudal Spanish conqueror seeks a feudal relationship with the emperor. His discourse sanctions a religious/imperial crusade that echoes back to la Reconquista, which presumes Monarchical recognition of his rights for implanting and transmitting civilization to the subdued (turning them into vassals or slaves). The neo-feudal conqueror (e.g., Bernal Díaz del Castillo), acknowledges he is the servant of the Crown, but articulates an expectation that he will be rewarded "for deeds rendered in the monarch's name" (Davis; 2000, p. 51; Castillo 1912, p. 693).

Cabeza de Vaca confronts the neo-feudal conqueror through his own imperial superaddressee, promoting the centralizing Spanish Crown's ideological perspective against the decentralizing neo-feudal conqueror's one (Bauer 2003, pp. 47, 48, 51; Castillo 1912, p. 693). From the very beginning to the end of La Relación, Cabeza de Vaca declares the "Sacra, Cesárea, Católica Magestad [Majestad]" as standing "above all the participants in the dialogue" and validating the legitimacy of his peaceful endeavor (Cabeza de Vaca 1542, sig. A1v; Bakhtin 1986, pp. 126, 78, 79; Bakhtin 1981, p. 342). The frontispiece of Cabeza de Vaca's narrative is adorned by the Hapsburg imperial eagle, establishing royal endorsement. He complements his exemplary true cristiano embodiment of self-sacrifice with his diligent service to the emperor through his narrative, recollecting everything (" memoria de todo") for the Caesarian (Imperial), Catholic Majesty, thus manifesting the sovereign's authority and power to both control the Indies and promote pacification "based on a corporate centralized state" against the neo-feudal conqueror (Molloy 1987, pp. 426, 427; Bauer 2003, pp. 38, 40, 48, 52; Cabeza de Vaca 1542, sig. A2 ${ }^{\mathrm{r}}$ ).

Cabeza de Vaca's and the neo-feudal conqueror's discourses conflict, distort, refract interpretations at certain points, indicating their superaddressees are not actually alike (Bakhtin 1981, p. 432). Nevertheless, their respective superaddressees incorporate the subjugated Africans, disregarding their diversity, fitting them into expected cristiano imperial hierarchical and social slots. Their ultimate authoritative witnesses categorize African slaves into two types: legally enslaved captives taken in just war and, under the doctrine of natural slavery, inferior people to be governed by superior ones. Africans are denied "all sorts of rights and claims based on birth" and "efforts to fuse blacks and persons of mixed ancestry into Spanish society produced significant tensions," for they are regarded "neither as entirely Christian (and thus not entirely rational) nor as entirely pure" (Martínez 2000, pp. 26, 27). Though the African slaves become Catholic, the cristiano imperial superaddressee portrays them as suspect, or as inauthentic, or incomplete. Cabeza de Vaca and the neo-feudal conqueror dovetail in presupposing the African slave's status as natural, entailing the recognition of the master's privilege (Olsen 1998, pp. 53, $54)$.

31 Spanish imperial discourse mandates that the only way to Christianize Africans is by enslaving them (Fredrickson 2002, pp. 39, 38). Sepúlveda's position that non-rational beings can "be made useful to the Spaniards and amenable to Christianity only by the application of force"-that is, through enslavement-very much coincides with Ambrose's 
view that "a fool is someone with permanent mental and moral deficiencies, who needs to be enslaved." Since his desires would destroy him, the fool therefore "would benefit by being enslaved" (Fredrickson 2002, pp. 36, 37; Garnsey 1996, p. 196.).

In La Relación, the conqueror's utterances capture and contain the subject "negro" as bond servant and empower the Christian master to convert the slave and punish a disobedient slave for his sake (Garnsey 1996, pp. 208, 209; Pagden 1982, pp. 111, 116). For Cabeza de Vaca and the neo-feudal conqueror, the term "negro" is part of the cristiano imperial value-laden language that confirms their true cristiano privilege.

However, as a slave/captive castaway, Cabeza de Vaca reveals himself to be the true cristiano by announcing he will bring the shipwrecked cristianos out of the barbarous lands and into the tierra cristiana: "que yo los passaría de los ríos y ancones que topássmos" (I will lead them across rivers and inlets that barred our way) (Cabeza de Vaca 1542, sigs. D5v , H2 v). Though the castaways Dorantes and Castillo are also slaves/captives of the natives, they are not the ones with the God-given mission to liberate the cristianos from such a sad and wretched captivity (sig. $\mathrm{H} 2^{\mathrm{v}}$ ).

Cabeza de Vaca's narrative presents the distinctions between his enslavement/captivity as a castaway and that of others, in part by drawing on three significant discourses concerning slavery that are embedded in the Spanish imperial source, from which the concept of good slave arises: the Apostle Paul, Bishop of Milan Ambro, and Augustine of Hippo (Bakhtin 1981, p. 429). From the cristiano imperial superaddressee's orientation, these discourses support Cabeza de Vaca's category of being the true cristiano and justifies Estevanico's bondage as that of a good slave, for even if the master is bad, this does "not release slaves from the necessity of serving willingly and patiently" (Garnsey 1996, p. 179).

Because of the dangers of assimilation into the indigenous world, resulting in effacement from the cristiano imperial context, Cabeza de Vaca articulates his suffering as esclavo/ cautivo cristiano as leading to his redeemer status. Admitting his sin (pecado) and accepting his enslavement/captivity, Cabeza de Vaca emulates Christ's role as a slave and submits to the will of God, who permits him to suffer for his sins so that he can take up his duty to convert and be the eye of the emperor (Cabeza de Vaca 1542, sigs. A1 ${ }^{\mathrm{v}}, \mathrm{A} 2^{\mathrm{r}}$; Rigby 2002, p. 219; Garnsey 1996, pp. 213, 218, 231, 217; Elliott 2006, p. 71; Bauer 2003, p. 74). Kun Yong Lee, arguing that Cabeza de Vaca reconstructs his experience by using Saint Paul as his prototype, comments on how Cabeza de Vaca "alludes to Paul's letter to the Colossians," in terms of sharing in the Passion of Jesus and in preaching "the gospel to the American Gentiles" (Lee 1999, p. 248). In La Relación, this embedded referential discursive source reinforces his redeemer role, accentuating his contrast with the untrue cristianos.

The Spanish Crown's utterances, though, are affected by "continuous and constant interactions with others" while seeking "efficient acquisition, control and exploitation" of the conquered (Bakhtin 1986, p. 89; Batchelder and Sanchez 2013, pp. 51, 58, 59). The Spanish Crown seeks wage labor in the Americas but political concerns allow slavery and the acceptance of the encomienda (Yeager 1995, pp. 846, 847, 857). At times, the Crown appears to attempt to eliminate native slavery and the encomienda system (e.g., the 1530 royal decree and the 1542 Leyes Nuevas), for they threaten the monarch's control (Elliott 2006, p. 286). At other times, the Monarchy shows support for forced labor, by issuing the requerimiento, authorizing the importation of African slaves to the Americas (e.g., 1510, 1518 , and 1530), and appearing to accept the Aristotelian doctrine on natural slavery and African slavery. As Spanish conquerors' competing discourses struggle over the 
"ownership of interpretative control and authority over words and signs," the Crown's contrary elements complicate the supposed consistency of the exclusive orientation of a superaddressee (Bauer 2003, p. 47; Yeager 1995, p.856).

Despite this, the problematic African voices in La Relación are assimilated, portraying their servitude as natural and as an accessible resource for the imperial endeavor. Although Estevanico the slave functions as a cristiano who performs his duties to the monarch, unlike Cabeza de Vaca, he is not permitted to submit petitions to gain royal favors based on the worthiness of his conduct while serving the monarch (Cabeza de Vaca 1542, sigs. E5 $\left.{ }^{\mathrm{v}}, \mathrm{D} 5^{\mathrm{v}}, \mathrm{F} 7^{\mathrm{v}}, \mathrm{H} 7^{\mathrm{r}}\right){ }^{6}$ Instead, Cabeza de Vaca's narrative discourse assumes that the subjugated Estevanico anticipates the wishes of the master and takes the initiative, thus acting as an element of stability (Harrill 2006, pp. 21, 33).

Narrative words and utterances carry the cristiano imperial ideological expression and evaluation about who is a true cristiano and who is not. Cabeza de Vaca's superaddressee accepts his received grace that frees him from his slave/captive state. However, Estevanico's acts are not evaluated in the same manner. This reinforces the existing structures of servitude for the "other" and points to the presuppositions embedded in the cristiano superaddressee, e.g., justifying enslavement under the promise of Christian redemption in the afterlife (Baptiste 1990, p. 9). In Augustinian terms, Estevanico's suffering will save his soul but not change his social status. Yet as a cristiano slave, he will be rewarded on the second coming (Garnsey 1996, pp. 213, 217). He gains the Church's formidable protection, and symbolic intimacy to the emperor, but is ineligible to submit a relación de méritos y servicios because of his slave status (Hensel 2007, p. 17; Markus 1970, pp. 11, 137, 141). Within the cristiano imperial social/political frame in La Relación, he appears to either accept his slave status or disagree with his personal situation yet consenting to the existence of the slave institution.

The result is that a cristiano imperial superaddressee recognizes that both Cabeza de Vaca and African slaves (Estevanico included) fall into the category cristianos. However, within this large group, each comprises a separate subset: Cabeza de Vaca, as redeemer, falls into the subset true cristiano, and the African slave in the incomplete cristiano one. The neofeudal Spanish conqueror fits into the false cristiano group. Cabeza de Vaca interprets his dire slave/captive experience as that of a socially legitimate true cristiano, for he is the recipient of grace, deflecting the neo-feudal conqueror's accusation he is not (Bakhtin 1990, p. 90). His imperial superaddressee supports his return to the tierra cristiana through God's grace to resume his duty to the sovereign and reinforces the African servants' expected obligations to the enterprise of fulfilling the unifying Catholic universal dominion (Voloshinov 1973, p. 103).

\section{The Presuppositions in the Cristiano Imperial Superaddressee's Silence Concerning Africans, Specifically Estevanico}

In La Relación, Cabeza de Vaca's lack of comment, at times, about the slavery of the "other" comes across as an argument from silence that assumes slavery is part of the natural order, or the result of mankind's sin (Garnsey 1996, pp. 243, 213, 214). A conqueror's text constructs a narrative that has "power over the exteriority", imposing order on it and enabling its transformation for his purposes (Rabasa 1993, pp. 55, 56). In 
Cabeza de Vaca's text, the dominance of silence about African slavery projects an external acceptance of it without the need for argument or reflection. Cabeza de Vaca's cristiano imperial superaddressee acknowledges the turning of his slave/captive status into redeemer while relegating Estevanico el negro to a subservient position, for Cabeza de Vaca is a true cristiano and Estevanico an incomplete one (Eltis 2000, p. 17). A cristiano/ Hispanic ideological background validates Cabeza de Vaca's redeemer acts while taking for granted-without articulation-that African slavery is God's just punishment of them and that cristiano masters are there to nurture the Christian faith in them.

41 On occasions, Cabeza de Vaca does argue against the mistreatment of indigenous people, his criticism paralleling sixteenth-century Spanish Dominican friar Bartolomé de Las Casas', who rejects the Spanish humanist, philosopher, and theologian Sepúlveda's universal values and encomienderos' practices (Wallerstein 2006, p. 40 ; Elliott 2006, pp. 99, 100). However, like Las Casas in his Memorial de remedios para las Indias (1516), Cabeza de Vaca accepts slavery (Baptiste 1990, p. 9). Las Casas "did not work for the freedom of all peoples of the world," and others followed this approach, e.g.: Jeronymites also advocate for the importation of African slaves to "alleviate the plight of the Taíno population" and support the perpetuation of the encomienda system and the taking of native slaves throughout Tierra Firme (Stone 2013, pp. 206, 207; Rivera 1992, pp. 192, 193). This once again reveals the complexity of an imperial superaddressee in flux.

Cabeza de Vaca's uterrances directed towards the cristiano imperial superaddressee presuppose that the status quo is understood and obeyed by all, but indirectly convey an Estevanico who needs through obedience and service to fulfill his Christian duty (Hirschkop 1999, p. 87). Such discourse obscures the dialogic give-and-take between him and el negro. Cabeza de Vaca filters Estevanico's voice through his superaddressee, confirming his limited options without using the word slave nor questioning his status (Bakhtin 1986, pp. 126, 122; Cabeza de Vaca 1542, sigs. C2 ${ }^{\mathrm{r}}$, D3 ${ }^{\mathrm{r}}$ ). At the end of La Relación, Estevanico is identified in more detail than before as "Estevanico ... negro alárabe, natural de Azamor," fixing him in the imperial context in an authoritative manner (Cabeza de Vaca 1542, sig. I3 ${ }^{\mathrm{r}}$; Adorno and Pautz 1999b, p. 417). His name identifies him as a Christian convert and, at this time, the diminutive form of Stephen is commonly assigned to "subalterns such as slaves and interpreters, African or Indian, in the service of Castilians" (Adorno and Pautz 1999b, p. 418; Adorno and Pautz 1999a, p. 83, note 3). Throughout the narrative, mainly through silence, Dorantes's ownership of Estevanico is never questioned nor is the difficult castaway period deemed as one that either emancipates him or denies the validity of his slave status, indicating that the status quo is supposedly understood by both the cristiano/Hispanic writer and his/her implicit reader. In an act that implies there are no other alternatives to his slave status, he is sold by Andrés Dorantes to Viceroy Antonio de Mendoza, who utilizes him as guide for Fray de Niza in search of the golden city, thus contributing to the imperial endeavor (Adorno and Pautz 1999b, p. 421).

Once Estevanico appears in La Relación as a castaway, there is no evidence he seeks to end his slave status. In contrast, another African (un negro), with the "christiano griego" Dorotheo Theodoro, did abandon the expedition after the Florida stranded men constructed barges and launched themselves into the sea (Cabeza de Vaca 1542, sig. C2 ${ }^{\mathrm{r}}$ ). Theodoro and a negro leave with natives to get water, even though his fellow cristianos are against this. Later, the natives refuse to return Theodoro and the negro, implying they have chosen to remain with them, and also want their people, who are being held hostage 
by the cristianos, to be released. The expeditionary members refuse to free the hostages, but they are unable to regain Theodoro and the negro (Adorno and Pautz 1999b, pp. 149; Cabeza de Vaca 1542, sig. C2 ${ }^{\text {r }}$; Oviedo 1992, pp. 174).

Later, once Estevanico becomes a físico (healer) he has opportunities to break away from his slave status, especially since the role makes possible indigenous social connections that can lead to his acceptance as a member of an indigenous community (Cabeza de Vaca 1542, sig. E6 ${ }^{v}$ ). Yet this does not occur.

Indigenous utterances and reactions in their engagement with the castaways disclose a different way to understand Estevanico's actions (and inactions) in regards to his bondage. At first, the natives perceive the expeditionary members as invaders (e.g., the Florida incidents). Nevertheless, there still exist possibilities of being accepted as part of an indigenous community. After being shipwrecked for some time somewhere on the coast of either present day northern Mexico or the state of Texas, U.S.A., the native communities reject the castaways, including Estevanico, due to cannibalistic acts, violence among the castaways, and their association with diseases that harm the natives (Cabeza de Vaca 1542, sigs. C7 $7^{\mathrm{v}}, \mathrm{C} 8^{\mathrm{r}}, \mathrm{D} 7^{\mathrm{r}}$ ). In addition, stories about invading Spanish forces attacking indigenous communities spread across the regions (Cabeza de Vaca 1542, sigs. $\left.\mathrm{E}^{\mathrm{v}}, \mathrm{E7}^{\mathrm{r}}, \mathrm{E} 7^{\mathrm{v}}\right)$. The indigenous people view Cabeza de Vaca and his companions as dangerous, lacking history and relationships to known groups, and fear the Spaniards and Estvanico, who by their very presence bring "all too often" death (Adorno 1991, p. 191). Even when it appears that the castaways as físicos have acquired power within the native cultural sphere, the natives utilize them, but do not incorporate them into their community, identifying the castaways, including Estevanico, as "them" rather than "us."

That the natives identify Estevanico as a member of the castaways is revealed, for instance, during the practice of a pillager/victim ritual, when the four castaways are fisicos and move westward inland from the coast. In conducting the ritual, the principales señores (indigenous leaders and/or chiefs) draw on their superaddressee and manage and develop the identity of the castaways in order to gain the goods of others, claiming that if a community does not turn over their goods, then they will feel the castaways' dark power. Their discourse labels the castaways, including Estevanico, as not simply healers but as potentially harmful and damaging people. Once the pillager group is successful in taking the goods of an unfortunate community, principales arise from the victimized native group and take up the previous looting group's narrative. They seek to secure success in the pillager/victim ritual-and thus provide for their particular communityby promoting the dark account of the castaways. Even if Estevanico as fisico desired to abandon his shipwreck companions at this point, the natives have tagged him as dangerous, denying him membership into their social groups.

Cabeza de Vaca, Dorantes, and Castillo use Estevanico el negro as an important intermediary between them and the indigenous people to maintain some authority as fisicos, gain knowledge of routes, and village information. This offers Estevanico options in regards to leaving his fellow cristianos and gaining his freedom (Cabeza de Vaca 1542, sigs. D3 ${ }^{r}, F^{v}$, G7v). But Estevanico's intermediary role does not, in fact, offer him a viable opportunity to break free, since the native superaddressee distances him as one of the perilous "other" (Cabeza de Vaca 1542, sigs. G4v , G7v; Gordon 2006, p. 184; Ahern 1993, pp. 227, 232).

Cabeza de Vaca's narrative never shows Estevanico as a threat to the expedition nor to the three surviving Spanish castaways nor as one who would abandon them. Estevanico is 
defined by the cristiano imperial superaddressee's discursive context as a subdued cristiano who must be a loyal servant and give obedience to church and Crown (Bakhtin and Medvedev 1985, 120). For instance, Nicolás de Ovando's royal instructions (16 September 1501) state "all African slaves approved for passage to the Indies" can only be "those born and raised under the jurisdiction of Christians," implying they are trustworthy (Adorno and Pautz 1999b, pp. 418, 419). Cabeza de Vaca identifies Estevanico as a "Christian, Spanish-speaking, Arabic-speaking black man" raised "under the jurisdiction of Christians," harnessing Estevanico to the imperial aims of the Spanish conquest (Adorno and Pautz 1999b, pp. 419, 418, 414, 415, 416, 421).

Cabeza de Vaca makes the point that no matter the harshness and bitterness of the shipwreck experience, el negro moves with the other three castaway cristianos as part of an inclusive group whose goal is reaching tierra cristiana while not being absorbed into the non-cristiano indigenous community. Without stating it directly, La Relación shows Estevanico as a good slave, who is a faithful servant of Dios and Vuestra Majestad. Cabeza de Vaca's discourse interprets Estevanico as serving his Christian master "without resentment", echoing elements of Paul's rhetoric (Garnsey 1996, pp. 176, 177). His utterances take for granted that Estevanico as a negro slave is a loyal, cooperating, and an unequal kind of cristiano. Cabeza de Vaca's cristiano imperial superaddressee stands as witness to the African slave's acquiescent to or silent support of the conquering endeavor.

Towards the last part of La Relación, on his way back to Spain, Cabeza de Vaca mentions a French pirate vessel, with its seized cargo ship, which attempts to capture the ship he is on. However, because nine Portuguese ships appear, the pirates are forced to flee, releasing the ship loaded with negro slaves ("cargada de negros") to confuse the approaching fleet and giving them time to get away (Cabeza de Vaca 1542, sig. H8v). Cabeza de Vaca does not elaborate on the Africans who are in bondage, supplying no further information. There is no utterance that points to a social/ethical problem concerning the slaves. Cabeza de Vaca's privileged position in relationship to them is clear, displaying no need to justify his social standing or their status. The cristiano imperial superaddressee contains the unspoken suppositions that (1) as pagans, Africans can be enslaved and (2) as legal merchandise, they are obtained "from areas outside of Spanish jurisdiction" (Pagden 1982, p. 33). 
continuation and/or imposition of the slave environment in the Spanish empire. Scrutinizing the cristiano imperial superaddressee in La Relación is crucial in deciphering the manner in which Cabeza de Vaca articulates the African slave role, such as Estevanico's, and the assumptions that form the metaphysical entity invoked as Sacred, Caesarian (Imperial), Catholic Majesty, who textually assimilates and/or silences Africans by denying or marginalizing utterances considered alien (Cabeza de Vaca 1542, sig. H8v; Bakhtin 1986, pp. 126, 137).

\section{BIBLIOGRAPHY}

Adorno, R. (1991). The Negotiation of Fear in Cabeza de Vaca's Naufragios. Representations, 33, 163-199.

Adorno, R. and Pautz, P. C. (Eds.). (1999a). Álvar Núñez Cabeza de Vaca: His Account, His Life, and the Expedition of Pánfilo de Narváez, Vol. 1. Lincoln: University of Nebraska Press.

Adorno, R. and Pautz, P. C. (Eds.). (1999b). Álvar Núñez Cabeza de Vaca: His Account, His Life, and the Expedition of Pánfilo de Narváez, Vol. 2 (Lincoln: University of Nebraska Press.

Adorno, R. and Pautz, P. C. (Eds.). (1999c). Álvar Núñez Cabeza de Vaca: His Account, His Life, and the Expedition of Pánfilo de Narváez, Vol. 3. Lincoln: University of Nebraska Press.

Ahern, M. (1993). The Cross and the Gourd: The Appropriation of Ritual Signs in the Relaciones of Álvar Núñez Cabeza de Vaca and Fray Marcos de Niza. In J. M. Williams and R. E. Lewis (Eds.), Early Images of the Americas: Transfer and Invention (pp. 215-244). Tucson: University of Arizona Press.

Bakhtin, M. M. (1990). Art and Answerability: Early Philosophical Essays by M. M. Bakhtin. M. Holquist and V. Liapunov (Eds.). V. Liapunov (Trans.). Austin: University of Austin Press.

Bakhtin, M. M. (1981). The Dialogic Imagination: Four Essays by M.M. Bakhtin. (M. Holquist Ed.). C. Emerson and M. Holquist (Trans.). Austin: University of Texas Press.

Bakhtin, M. M. (1986). Speech Genres and Other Late Essays. C. Emerson and M. Hoquist (Eds.). V. W. McGee (Trans.). Austin: University of Texas Press.

Bakhtin, M. M. and Medvedev, P. N. (1985). The Formal Method in Literary Scholarship: A Critical Introduction to Sociological Poetics. Albert J. Wehrle (Trans). Cambridge: Harvard University Press.

Batchelder, R. W. and Sanchez, N. (2013). The Encomienda and the Optimizing Imperialist: an Interpretation of Spanish Imperialism in the Americas. Public Choice, 156 (1-2), 45-60.

Baptiste, V. N. (1990). Bartolomé de Las Casas and Thomas Moote's Utopia: Connections and Similarities. Culver City, California: Labyrinthos.

Bauer, R. (2003). The Cultural Geography of Colonial American Literature: Empire, Travel, Modernity. Cambridge: Cambridge University Press.

Cabeza de Vaca, Á. N. (1542). La Relación. Zamora: Augustin de Paz y Juan Picardo. 
Carreño, A. (1987). “Naufragios” de Alvar Núñez Cabeza de Vaca: Una retórica de la crónica colonial. Revista Iberoamericana, 53 (140), 499-516.

Castillo, B. D. del. (1912). Historia Verdadera de la Conquista de la Nueva España. Madrid: Espasa Calpe.

Columbus, C. (1994). Account of the Fourth Voyage. In P. E. Taviani, C. Varela, J. Gil, and M. Conti (Eds.), L. F. Farina and M. A. Beck (Trans.), Christopher Columbus: Accounts and Letters of the Second, Third, and Fourth Voyages, Vol. VI, part 1 (pp. 130-159). Roma: Instituto Poligrafico e Zecca Dello Stato Librería Dello Stato.

Dandelet, T. J. (2001). Spanish Rome 1500-1700. New Haven: Yale University Press.

Davis, E. B. (2000). Myth and Identity in the Epic of Imperial Spain. Columbia: University of Missouri Press.

Elliott, J. H. (2006). Empires of the Atlantic World: Britain and Spain in America 1492-1830. New Haven, Yale University Press.

Elliott, J. H. (1989). Spain and Its World 1500-1700. New Haven: Yale University Press.

Eltis, D. (2000). The Rise of African Slavery in the Americas. Cambridge: Cambridge University Press.

Fletcher, R. (1992). Moorish Spain. Berkeley: University of California Press.

Forbes, J. D. (1993). Africans and Native Americans: The Language of Race and the Evolution of Red-Black Peoples. Chicago: University of Illinois Press.

Fredrickson, G. M. (2002). Racism: A Short History. Princeton: Princeton University Press.

Garnsey, P. (1996). Ideas of Slavery from Aristotle to Augustine. Cambridge: Cambridge University Press.

Goodman, N. (2005). Mercantilism and Cultural Difference in Cabeza de Vaca's Relación. Early American Literature, 40 (2), 229-250.

Gordon, R. A. (2006). Following Estevanico: The Influential Presence of an African Slave in Sixteenth-century New World Historiography. Colonial Latin American Review, 15 (2), 183-206.

Greenblatt, S. (1991). Marvelous Possessions: The Wonder of the New World. Chicago: The University of Chicago Press.

Harrill, J. A. (2006). Slaves in the New Testament: Literary, Social, and Moral Dimensions. Minneapolis: Fortress Press.

Hirschkop, K. (1999). Mikhail Bakhtin: An Aesthetic for Democracy. New York: Oxford University Press.

Invernizzi, S. C. (1987): Naufragios e Infortunios: Discurso que Transforma Fracasos en Triunfos. Revista Chilena De Literatura, 29, 7-22.

Lampe, A. (2008). Religious Intolerance versus Religious Pluralism in Latin American History. In J. M. Vigil, L. Tomita, and M. Barros (Eds.), Along the Many Paths of God (pp. 15-29). London: Transaction Publishers.

Lee, K. J. (1999). Pauline Typology in Cabeza de Vaca's "Naufragios". Early American Literature, $34 / 3,241-262$.

Lewis, R. E. (1982). “Los naufragios” de Alvar Núñez: historia y ficción.” Revista Iberoamericana, 48 (120), 681-694. 
Markus, R. (1970). Saeculum: History and Society in the Theology of St. Augustine. Cambridge: Cambridge University Press.

Martínez, M. E. (2000). Space, Order and Group Identities in a Spanish Colonial Town: Puebla de los Angeles. In L. Roniger and T. Herzog (Eds.), The Collective and the Public in Latin America: Cultural Identities and Political Order; (pp. 13-36). Portland: Sussex Academic Press.

Molloy, S. (1987). Alteridad y Reconocimiento en los Naufragios de Alvar Núñez Cabeza de Vaca. Nueva Revista De Filología Hispánica, 35 (2), 425-449.

Nirenberg, D. (2007). Race and the Middle Ages: The Case of Spain and Its Jews. In M. R. Greer, W. D. Mignolo, and M. Quillligan (Eds.), Rereading the Black Legend: The Discoursees of Religious and Racial Differences in the Renaissance Empires (pp. 71-87). Chicago: University of Chicago Press.

Novikoff, A. (2005). Between Tolerance and Intolerance in Medieval Spain: An Historiographic Enigma. Medieval Encounters, 11 (1-2), 9-36.

Olsen, M. M. (1998). Negros Horros and Cimarrones on the Legal Frontier of the Caribbean: Accessing the African Voice in Colonial Spanish American Texts. Research in African Literatures, 29 (4), 52-72.

Oviedo, G. F. de (1992). Historia General y Natural de Las Indias, Vol. II. J. P. de T. Bueso (Ed.). Madrid: Atlas.

Pagden, A. (1982). The Fall of Natural Man: the American Indian and the Origin of Comparative Ethnology . New York: Cambridge University Press.

Pastor, B. (1992). The Armature of Conquest: Spanish Accounts of the Discovery of America, 1492-1589. Stanford: Stanford University Press.

Rabasa, J. (1993). Inventing America: Spanish Historiography and the formation of Eurocentrism. Norman: University of Oklahoma Press.

Reséndez, A. (2007). A Land So Strange: The Epic Journey of Cabeza de Vaca. New York: Basic Books. Restall, M. (2000). Black Conquistadors: Armed Africans in Early Spanish America. The Americas, 57 (2), 171-205.

Rigby, P. (2002). The Role of God's “Inscrutable Judgment” in Augustin's Doctrine of Predestination. Augustinian Studies, 33/2, 213-222.

Rivera, L. N. (1992). A Violent Evangelism: The Political and Religious Conquest of the Americas. Westminster: John Knox Press.

Salisbury, J. E. (2006). In Vain Have I Smitten Your Children: Augustine Defines Just War. In R. J. Hoffmann (Ed.), The Just War and Jihad: Violence in Judaism, Christianity, and Islam (pp. 203-216). Amherst, New York: Prometheus Books.

Silke H. (2007). Africans in Spanish-America: Slavery, Freedom and Identities in the Colonial Era. Indiana, 24, 15-37.

Smith, C. L. (2012). Beyond the Mediation: Esteban, Cabeza de Vaca's Relación, and a Narrative Negotiation. Early American Literature, 47 (2), 267-291.

Spitta, S. (1993). Chamanismo y cristianidad: una lectura de la lógica intercultural de los Naufragios de Cabeza de Vaca. Revista de crítica literaria latinoamericana, 38, 317-330.

Stone, E. W. (2013). America's First Slave Revolt: Indians and African Slaves in Española, 1500-1534. Ethnohistory, 60 (2), 195-217. 
Vinson, B. (April 2000). Race and Badge: Free-Colored Soldiers in the Colonial Mexican Militia. The Americas, 56 (4), 471-496.

Voloshinov,V. N. (1973). Marxism and the Philosophy of Language. L. Matejka and I. R. Titunik (Trans.). Cambridge: Harvard University Press.

Wallerstein, I. (2006). European Universalism: the Rhetoric of Power. New York: The New York Press.

Yeager, T. J. (1995). Encomienda or Slavery? The Spanish Crown's Choice of Labor Organization in Sixteenth Century Spanish America. The Journal of Economic History, 55 (4), 842-859.

\section{NOTES}

1. I follow the original orthography in La Relación. La Relación English translations are my own.

2. There is another survivor of the Narváez Expedition, Juan Ortiz (Joan Ortiz), who goes back to Cuba with the ships after Narváez leads a group of expeditionaries into the interior of Florida. When Narváez' wife hears nothing of her husband, she sends Ortiz with 20 or 30 others in a small ship back to Florida to search for him. When the ship arrives at a bay (possilby Tampa Bay), the sailors see on the beach what appears to be a note attached to a stick or reed. Ortiz and several other men go to investigate, resulting in his capture by a large number of warriors. In 1539, Ortiz makes contact with Hernando de Soto's men, who almost kill him, thinking him a native. He yells out, "Señores, por Dios y de Sancta María no me matéis: que yo soy cristiano." He then joins the De Soto Expedition as an interpreter.

3. The Crusades were military expeditions by European Christians in the eleventh, twelfth, and thirteenth centuries which attempted to regain land they called the Holy Land from the Muslims. 4. La Reconquista (718-1492) refers to the struggle between Christian forces and Moorish forces for the Iberian Peninsula that is crucial in the development of the Castilian ideological basis for what becomes the Spanish Empire.

5. The encomienda is a grant by the Spanish Crown of the right of the grantee to receive the labor and tribute of indios within a certain territory. See the following landmark and fundamental works on the encomienda S. Zavala (1973). La encomienda Indiana, 2nd edición. Mexico City, Editorial Porrúa; L. B. Simpson (1950). The Ecomienda in New Spain. Berkeley, University of California Press.

6. For textual Afro-Latin American voices revealed through complex networks and institutions see K. J. McKnight's and Leo J. Garofalo's (Eds.) (2009). Afro-Latino Voices: Narratives from the Early Modern Ibero-Atlantic World, 1550-1812. Indianapolis: Hackett Publishing Company. One can read R. A. Gordon's article, (2006). "Following Estevanico: The Influential Presence of an African Slave in Sixteenth-century New World Historiography," Colonial Latin American Review 15 (2), 183-206, concerning the "references to Esteban made by several authors other than Cabeza de Vaca."

\section{ABSTRACTS}

Based on Cabeza de Vaca's La Relación 1542 manuscript, this paper analyzes how, during his castaway period, his discourse constructs the nature of his captivity in contrast to that of the African slave. By utilizing Mikhail Bakhtin's concept of the superaddressee-who in a dialogue 
subordinates all to its contextual definition-this paper reveals how Cabeza de Vaca's narrative interprets his slave category in contrast to that of Africans.

Basado en el manuscrito de Cabeza de Vaca, La Relación (1542), este artículo analiza cómo, en su período de náufrago, el autor construye un discurso que contrasta su "cautiverio" con el de los esclavos africanos. Mediante la utilización del concepto de "súper-destinatario" (que en un diálogo subordina todo a su definición contextual) de Mikhail Bakhtin el trabajo revela cómo en su narrativa Cabeza de Vaca interpreta su esclavitud contrastándola con la de los africanos.

INDEX

Keywords: superaddressee, utterance, cristiano, silence, slave/captive, Negro.

Palabras claves: súper-destinatario, declaración, cristiano, silencio, esclavo/cautivo, negro. 